\title{
TEN-YEAR PLAN FOR DECONTAMINATION AND DECOMMISSIONING FOR MOUND LABORATORY
}

\author{
Sam S. Freeman
}

June 30, 1977

\author{
DISCLAIMER
}

This report was prepared as an account of work sponsored by an agency of the United States Government. Neither the United States Government nor any agency thereof, nor any of their employees, makes any warranty, express or implied, or assumes any legal liability or responsibility for the accuracy, completeness, or usefulness of any information, apparatus, product, or process disclosed, or represents that its use would not infringe privately owned rights. Reference herein to any specific commercial product, process, or service by trade name, trademark, manufacturer, or otherwise does not necessarily constitute or imply its endorsement, recommendation, or favoring by the United States Government or any agency thereof. The views and opinions of authors expressed herein do not necessarily state or reflect those of the United States Government or any agency thereof.

\section{MONSANTO RESEARCH CORPORATION}

A Subsidiary of Monsanto Company

\section{MOUND LABORATORY \\ Miamisburg, Ohio 45342 \\ operated for}

\section{UNITED STATES ENERGY RESEARCH AND DEVELOPMENT ADMINISTRATION}

U. S. Government Contract No. EY-76-C-04-0053

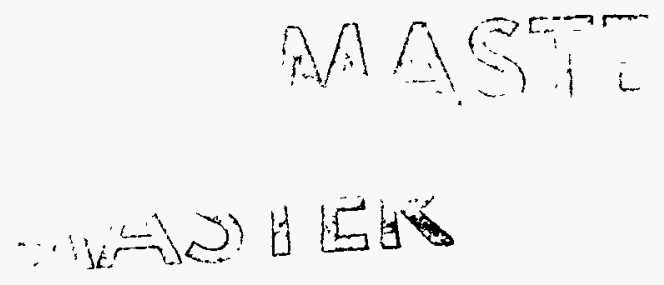


June 30,1977

Mr. Jose A. Chacon, Area Manager

U. S. Energy Research and Development Administration

Dayton Area Office

P. 0. Box 66

Miamisburg, Ohio 45342

Dear Mr. Chacon:

Planning for Decontamination and Decommissioning Letter of December 8, 1976, H. E. Roser to J. A. Chacon*

As I indicated in my letter to you, dated January 25, 1977, we are submitting our short and long range plans for decontamination and decommissioning projects at Mound Laboratory.

A11 projects are 1isted, including those that have been submitted in the form of Proposals (189's) and a Line Item for FY 1978 and FY 1979. The projects extend into the planning period of FY 1980 through FY 1989.

The projects are identified by site location, by building and by programs. The descriptions, level of decontamination and costs are by project, but they are also subdivided for purposes of prioritization and year of funding.

The projects for the removal of contaminated soil, as previously identified in Mound's "Radioactive Waste Management Site Plan" are not included at this time. These projects, which will be added at a later date, are discussed in the body of this report.

If you require any additional information regarding this plan, please advise.

Very truly yours,

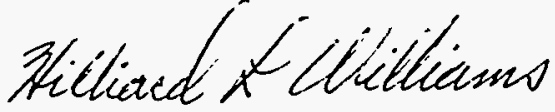

Hilliard L. Williams

Director, Engineering

HLW : pg

*See Appendix $-2-$ 
MOUND LAB DECOMISSIONING AND DECONTAMINATION PROJECTS

PRIORITIES AND COSTS

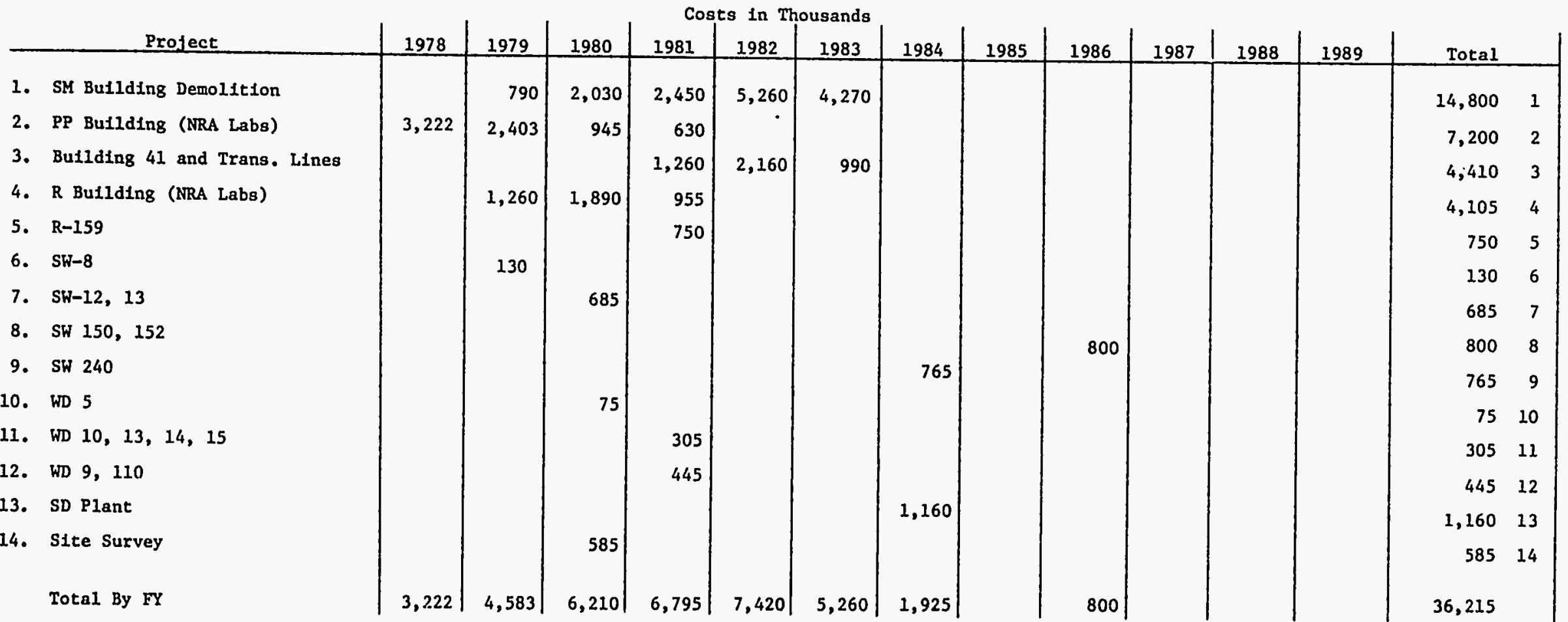




\title{
TEN-YEAR PLAN FOR DECONTAMINATION AND DECOMMISSIONING FOR MOUND LABORATORY
}

\author{
Sam S. Freeman
}

June 30, 1977

\section{DISCLAIMER}

This report was prepared as an account of work sponsored by an agency of the United States Government. Neither the United States Government nor any agency thereof, nor any of their employees, makes any warranty, express or implied, or assumes any legal liability or responsibility for the accuracy, completeness, or usefulness of any information, apparatus, product, or process disclosed, or represents that its use would not infringe privately owned rights. Reference herein to any specific commercial product, process, or service by trade name, trademark, manufacturer, or otherwise does not necessarily constitute or imply its endorsement, recommendation, or favoring by the United States Government or any agency thereof. The views and opinions of authors expressed herein do not necessarily state or reflect those of the United States Government or any agency thereof.

\section{MONSANTO RESEARCH CORPORATION}

A Subsidiary of Monsanto Company

\section{MOURD IABORATORY}

\author{
Miamisburg. Ohio
}

45342

operated for

\section{UNITED STATES ENERGY RESEARCH AND DEVELOPMENT ADMINISTRATION}

U. S. Government Contract No. EY-76-C-04-0053

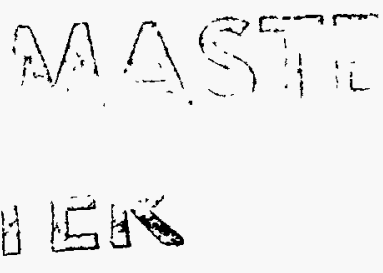




\section{Monsanto}

\section{MOUND LABORATORY}

Operated for the United States Energy

Research and Development Administration

June 30,1977

Mr. Jose A. Chacon, Area Manager

U. S. Energy Research and Development Administration

Dayton Area Office

P. 0. Box 66

Miamisburg, Ohio 45342

Dear Mr. Chacon:

Planning for Decontamination and Decommissioning Letter of December 8, 1976, H. E. Roser to J. A. Chacon*

As I indicated in my letter to you, dated January 25, 1977, we are submitting our short and long range plans for decontamination and decommissioning projects at Mound Laboratory.

All projects are listed, including those that have been submitted in the form of Proposals (189's) and a Line Item for FY 1978 and FY 1979. The projects extend into the planning period of FY 1980 through FY 1989.

The projects are identified by site location, by building and by programs. The descriptions, level of decontamination and costs are by project, but they are also subdivided for purposes of prioritization and year of funding.

The projects for the removal of contaminated soil, as previously identified in Mound's "Radioactive Waste Management Site Plan" are not included at this time. These projects, which will be added at a later date, are discussed in the body of this report.

If you require any additional information regarding this plan, please advise.

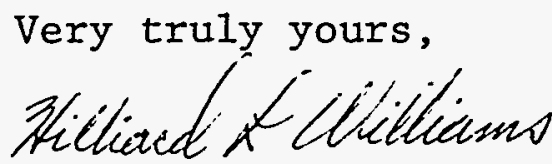

Hilliard L. Williams

Director, Engineering

HLW : pg

*See Appendix

$-2-$

Monsanto Research Corporation

P. O. Box 32

Miamisburg, Ohio 45342

(513) $866-7444$ 
Summary

The ten-year plan for decontamination and decommissioning for Mound Laboratory consists of 14 projects including three which are identified as starting prior to FY 1980 but extend into the period FY 1980 through FY 1989. The total cost of $\$ 36,215,000$ in FY 1979 dollars, as shown on the following chart, does not include the cost of the removal of contaminated soil identified in Mound's "Radioactive Waste Management Site Plan." There is insufficient information at this time to make an estimate of this cost. However, by early FY 1981, the data necessary to make an estimate will be available from the site survey, and the ten-year plan can then be amended to include the cost for removal of the contaminated soil.

The ten-year plan will also provide usable space for future programs in the Plutonium Processing (PP), Research (R), Semi-Works (SW), and Waste Disposal (WD) Buildings as follows:

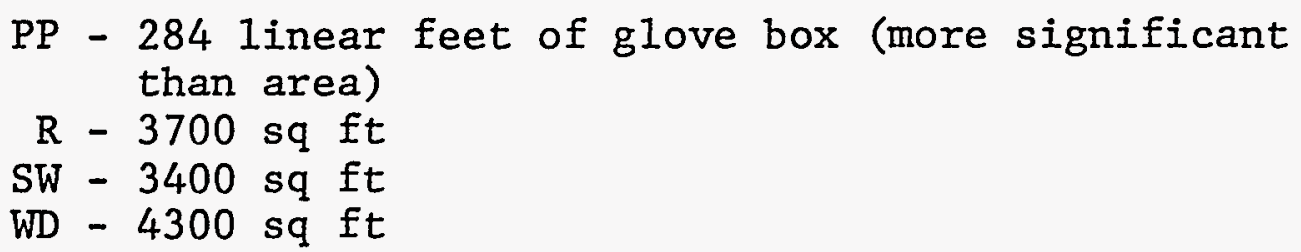
than area)$$
\mathrm{R}-3700 \mathrm{sq} f t
$$$$
\mathrm{SW}-3400 \mathrm{sq} f t
$$$$
\text { WD }-4300 \mathrm{sq} \mathrm{ft}
$$

The schedule as shown is the probable chronological priority.

Criteria for Developing the Plan

1. The guidelines for establishing the level of decontamination and decommissioning are those supplied in H. E. Roser's memorandum of December 8, 1976 (see Appendix).

2. The method of determining the final average contamination level of soil after decontamination is by core sampling and laboratory analysis to determine quantities on a grid of the contaminated area. The mass of soil used in the calculation of concentration will include the mass of the compacted back fill. Localized pockets of high levels of contamination will be removed even if the average contamination calculates to less than $11 \mathrm{pico} \mathrm{Ci} / \mathrm{g}$ of soil.

3. The level of decontamination of the laboratories is "extensive" in all cases as it is not feasible, at this time, to assume the equipment and glove boxes can be 
MOUND LAB DECOMMISSIONING AND DECONTAMINATION PROJECTS

PRIORITIES AND COSTS

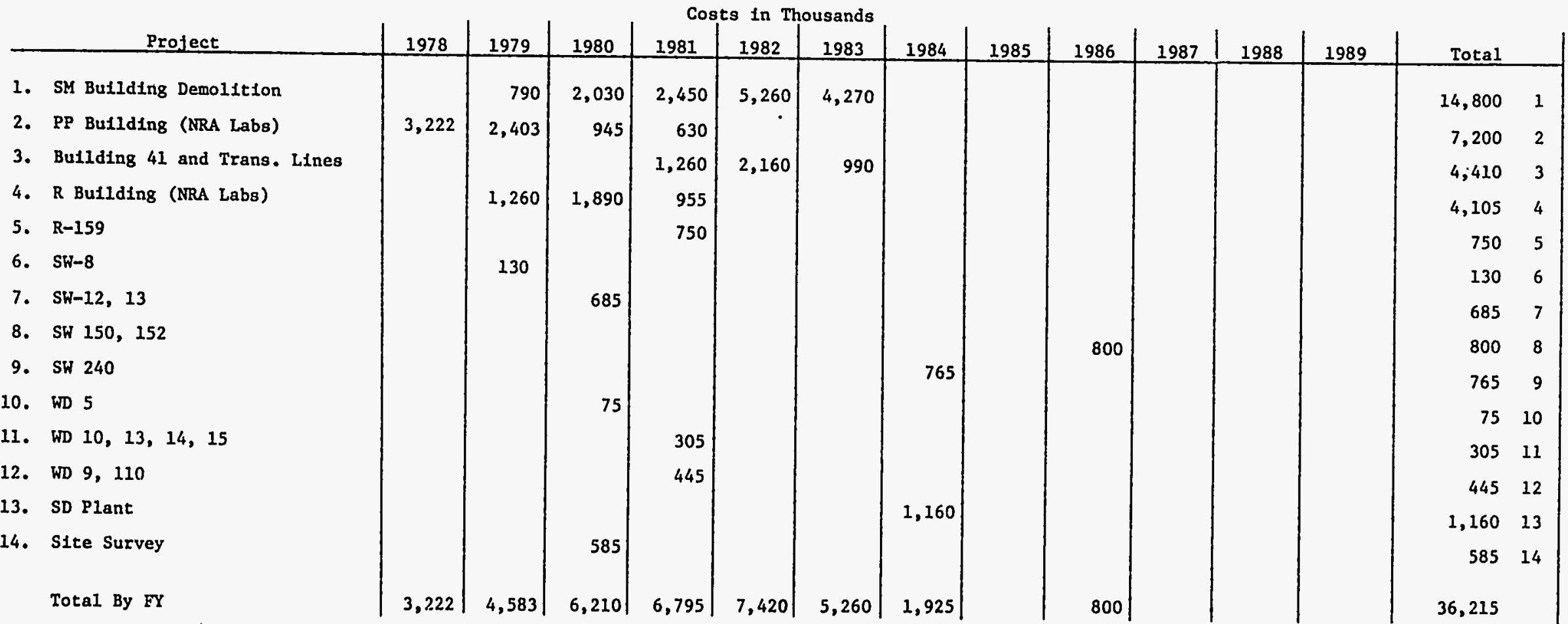


utilized for future programs. However, as plans are developed to utilize these laboratories, due consideration will be given to the possibility of reducing the level of decontamination.

4. Prioritization is based upon the logic for phasing out the functions, need for the decontaminated facilities, the leveling of the funding and availability of resources over the ten-year period.

5. Funding is indicated for those projects where guidance has been received. Funding for all other projects is indicated as indeterminate.

6. Site projects for the removal of contaminated soil are incomplete due to insufficient information on previously identified contaminated areas. Therefore, a project has been added to obtain the information necessary to estimate the cost of decontaminating the soil. When the information is available, the ten-year plan will have to be amended to incorporate these previously identified areas or any other areas identified by the survey.

Project Description, Justification and Funding

1. Special Metallurgical (SM) Building

a) Description

This project will remove the Special Metallurgical

(SM) Building at Mound Laboratory which is contaminated with Plutonium-238. This 23,000 square-foot structure (see Figure 1 ) is comprised of an open contaminated area of $13,500 \mathrm{sq}$ ft (the "Ball Room") and an uncontaminated area of $9,500 \mathrm{sq} f t$. The uncontaminated area includes offices, the existing Plutonium Processing (PP) area change room, laboratories, maintenance shops, and building services. In addition, contaminated support areas will be removed including underground "low risk" waste tanks, the Redrumming and Repackaging ( $R \& R$ ) Building (324 sq $f t$ ), the ventilation exhaust stack and contaminated earth under and in the near vicinity to the structures. 


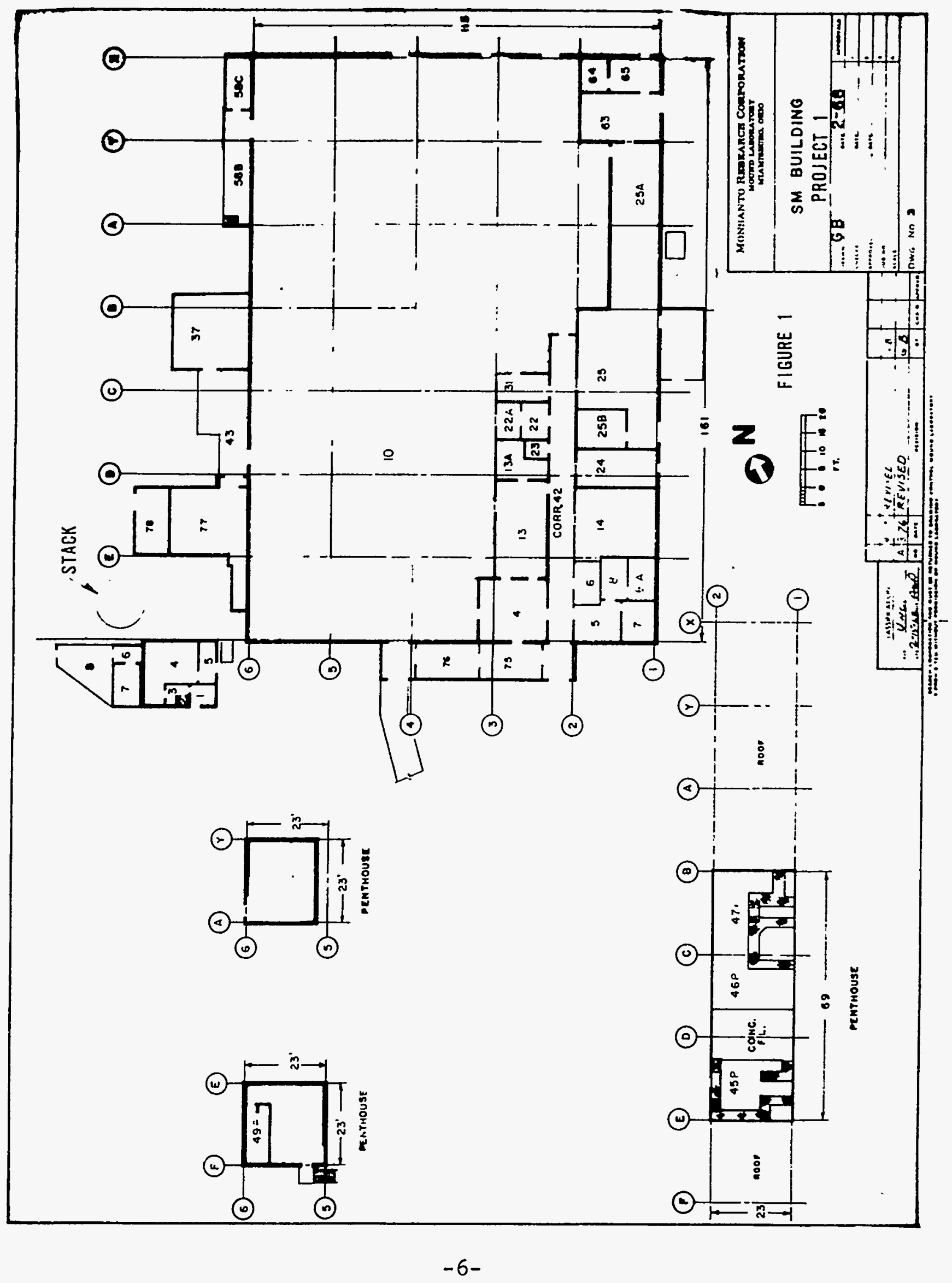


To accomplish this removal, Building 36 nearby must be refurbished to provide office space for personnel displaced from the SM Building. A new main exhaust fan and short stack must be installed for the PP Building so that the exhaust stack and fan can be removed. Utility services that are presently routed through the SM Building must also be redistributed.

In support of the actual removal effort existing technology related to contamination survey and fixing techniques, structural dismantling and packaging methods, and transportation and disposal methods will be improved. Potential personnel and environmental exposures will also be analyzed. The new disposal packages that are anticipated to be developed, designed and fabricated to support the removal project will require Government approvals, as will their associated transportation and disposal methods.

b) Justification

The hazards associated with the continued existence of the SM Building are unacceptable, because Energy Research and Development Administration (ERDA), Monsanto Research Corporation (MRC) and members of the general public are not deriving any benefits from the contaminated portion of the SM Building. The existence of the SM Building is inconsistent with the philosophy of "as low as practicable" (ALAP) and the intent of Executive Order 11752, "Prevention, Control, and Abatement of Air and Water Pollution at Federal Facilities." It will also eliminate the need for continuing maintenance and surveillance.

c) Funding

This project was initially to be funded as a Line Item, but on instructions from ERDA, a Schedule $189 \mathrm{C}$ was submitted on March 28, 1977.

References: Letter of transmission D. L. Balsmeyer to J. A. Chacon dated March 28, 1977.

Schedule 189 C 77-03-127 dated March 1, 1977. 
2. $\mathrm{PP}$ Building

a) Description

Two hundred eighty four linear feet of glove boxes with contents and the support facilities in Laboratories $\mathrm{A}-1, \mathrm{~A}-2, \mathrm{~B}-1, \mathrm{C}-1, \mathrm{C}-2, \mathrm{C}-3, \mathrm{C}-4, \mathrm{~F}-2, \mathrm{~F}-3$ and $\mathrm{F}-4$ will be removed and the rooms restored (extensive decontamination). Glove Box 601 in F-1 will also be removed (see Figure 2).

b) Justification

Based on current Division of Nuclear Research and Application (NRA) program guidance, the NRA recovery area on the second floor of PP Building became inactive in FY 1975, and additional portions will become inactive in late FY 1977. It is less hazardous to remove the contaminated equipment than it is to continue to provide maintenance and surveillance. The PP Building will retain the capability to process fuel and to encapsulate the milliwatt generator. It will also retain analytical facilities to support this program plus all building and process services.

c) Funding

Based upon the concept that the last building user budgets for final decontamination, this project will be funded by NRA.

3. Building 41 and Alpha Waste Transfer Lines

a) Description

This project will remove the waste pump station (Building 41) and the two underground polypropylene line pipe lines that connect to it from the Plutonium Processing and the Waste Disposal Buildings (see Figure 3). Contaminated earth under and near the building and lines will also be removed.

b) Justification

When the transfer lines began to show signs of deterioration and became unreliable and difficult to maintain, a Waste Solidification Facility for drumming wastes was 


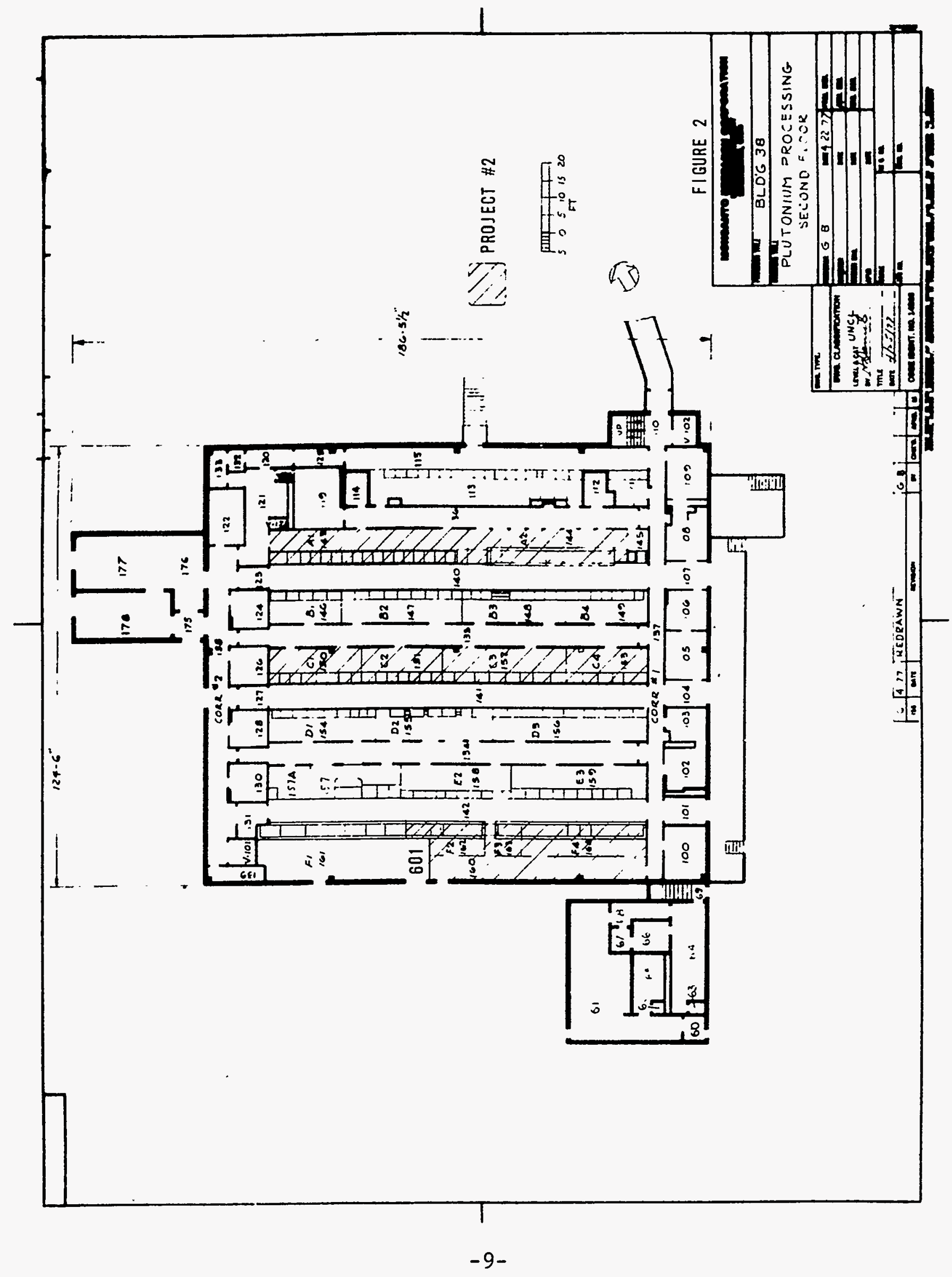




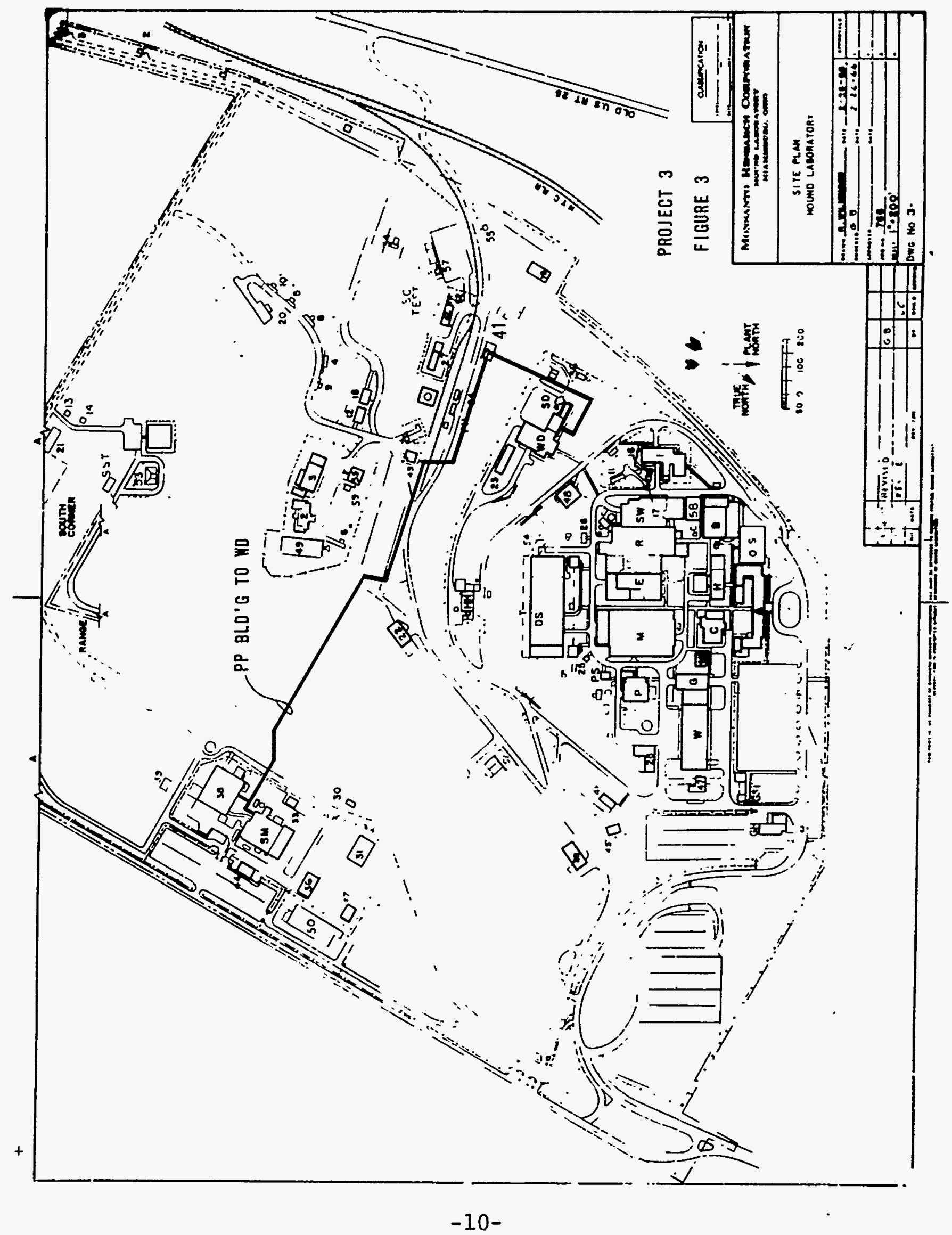


constructed at the PP Building. The higher activity alpha liquid waste line was abandoned. The low risk alpha waste will be transferred by tank truck on completion of the loading and unloading stations (a FY 1976 GPP Project). This will permit the abandonment of the entire transfer system from PP to WD. Continuing surveillance of the system is difficult, and its complete removal will eliminate potential leaks to the environment.

c) Funding

Based upon the concept that the last building user budgets for final decontamination, this project will be funded by NRA.

4. $\mathrm{R}$ Building (NRA Labs)

a) Description

Two hundred fifteen linear feet of glove boxes with contents and supporting facilities in Laboratories $\mathrm{R}-120, \mathrm{R}-217, \mathrm{R}-130, \mathrm{R}-131, \mathrm{R}-145$ and $\mathrm{R}-147$ wi11 be removed and the labs restored (extensive decontamination) (see Figure 4).

b) Justification

Based on current NRA program guidance, these laboratories, where activities such as process development, process engineering, particle coating, vacuum hot pressing of Pu-Mo-Cermet (PMC) and Pressed Plutonium Oxide (PPO) fuel forms, metallography and excapsulation were conducted, will become inactive in FY 1977. It is less hazardous to remove the contaminated equipment than it is to continue to provide maintenance and surveillance. The space is also valuable for potential future programs.

c) Funding

Based upon the concept that the last building user budgets for final decontamination, this project will be funded by NRA. 


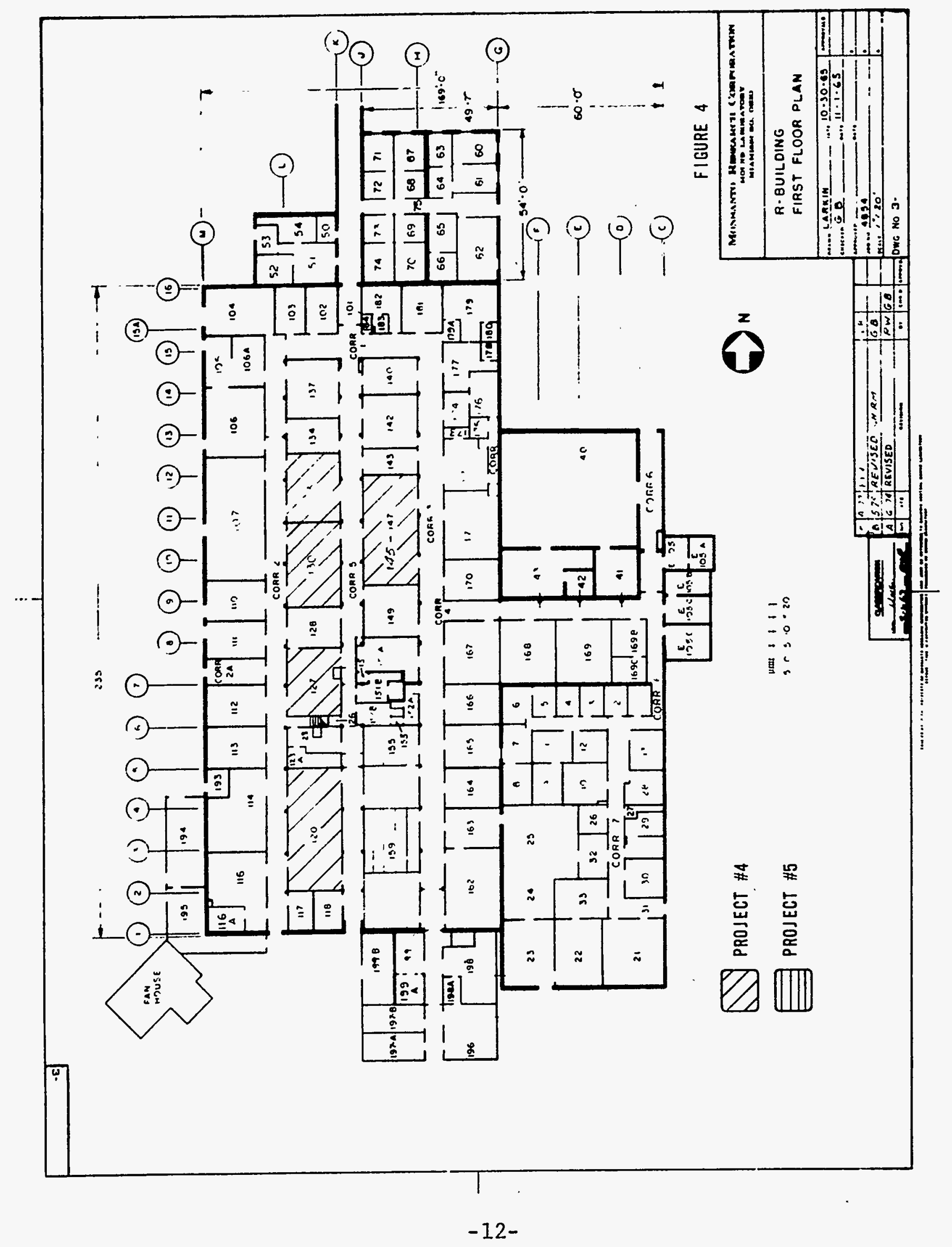


5. R Building (Lab R-159)

a) Description

This large laboratory ( $1150 \mathrm{sq} f t$ ) has undergone a number of changes in programs. The current work is being performed in existing glove boxes and fume hoods at the south and north ends of the lab. All of the facilities in between consisting of approximately 43 linear feet of glove box, fume hoods, associated equipment, and two inert atmosphere recirculating systems, are to be completely removed (extensive decommissioning) (see Figure 4).

b) Justification

Based on present program guidance, there is no apparent need for the inactive equipment, either now or in the future. Removal of this contaminated equipment reduces the potential hazard of release to the environment. It will also provide space for future programs.

c) Funding

To be determined.

6. SW Building (SW 8)

a) Description

The old solids recovery line of approximately 40 linear feet of glove box and supporting equipment will be removed and the lab restored (extensive decontamination) (see Figure 5).

b) Justification

A new recovery laboratory is under construction in R 107 with greater capabilities than the existing line which it will replace. Also, the space is needed for installation of equipment for the Line Item, "Tritium Liquid Waste Recovery System."

c) Funding

A Line Item has been submitted for the FY 1979 budget 


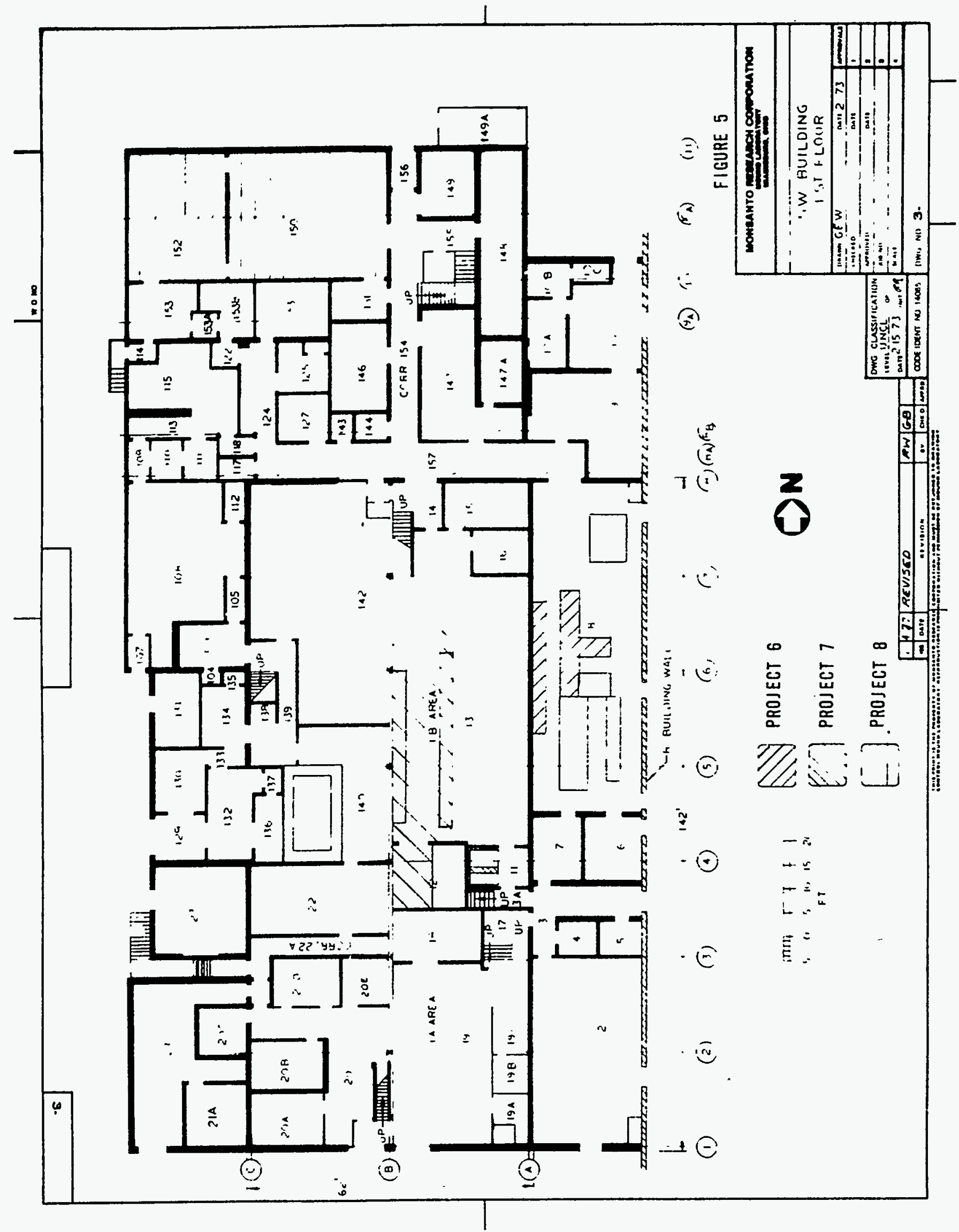


entitled, "Tritium Liquid Waste Recovery System." It includes the cost of the extensive decontamination of this obsolete recovery facility to allow for the installation of the new Line Item.

7. SW Building (SW 12 and SW 13)

a) Description

About 36 linear feet of glove box line and supporting equipment on the west side of SW 13 will be removed and that part of the $1 \mathrm{ab}$ restored (extensive decontamination).-

The recirculating inert atmosphere system on the west side of SW 12 which services the obsolete glove box line will be removed and the room restored (extensive decontamination) (see Figure 5).

b) Justification

Based upon current program guidance, this equipment is no longer required. It is less hazardous to remove this contaminated equipment than it is to continue to provide maintenance and surveillance. It is also prime space which could be used for some future program.

c) Funding

To be determined.

8. SW Building (SW 150 and 152)

a) Description

A11 of the equipment in SW 150 and 152 consisting of 100 linear feet of glove boxes, fume hoods, 500 ton press, and support facilities will be removed and the rooms restored (extensive decontamination) (see Figure 5).

b) Justification

Based upon current program guidance, this laboratory will not be required to support process development. 
The anticipated level of support can be handled in SW 142. This contaminated equipment will be difficult to maintain and keep under surveillance so it would be less hazardous to remove it completely. The space will also be useful for some future program.

c) Funding

To be determined.

9. SW Building (SW 240)

a) Description

This $1 \mathrm{ab}$ and all of the glove boxes and supporting equipment will be extensively decontaminated (see Figure 6).

b) Justification

Based upon current program guidance, this laboratory will not be required beyond FY 1982. It is less hazardous to remove this equipment than it is to continue to provide maintenance and surveillance. It is also prime space which could be used for some future program.

c) Funding

To be determined.

10. Waste Disposal Building (WD 5)

a) Description

The centrifuge, sludge mixer and associated equipment, and services in this room will be removed and the room restored (extensive decontamination) (see Figure 7).

b) Justification

The waste disposal process has been modified with a large reduction in sludge volume. Also, the sludge contains a high percentage of hydroxide as a result of increasing the $\mathrm{pH}$ and is not easily dewatered by centrifugation. Therefore, this equipment for reducing 


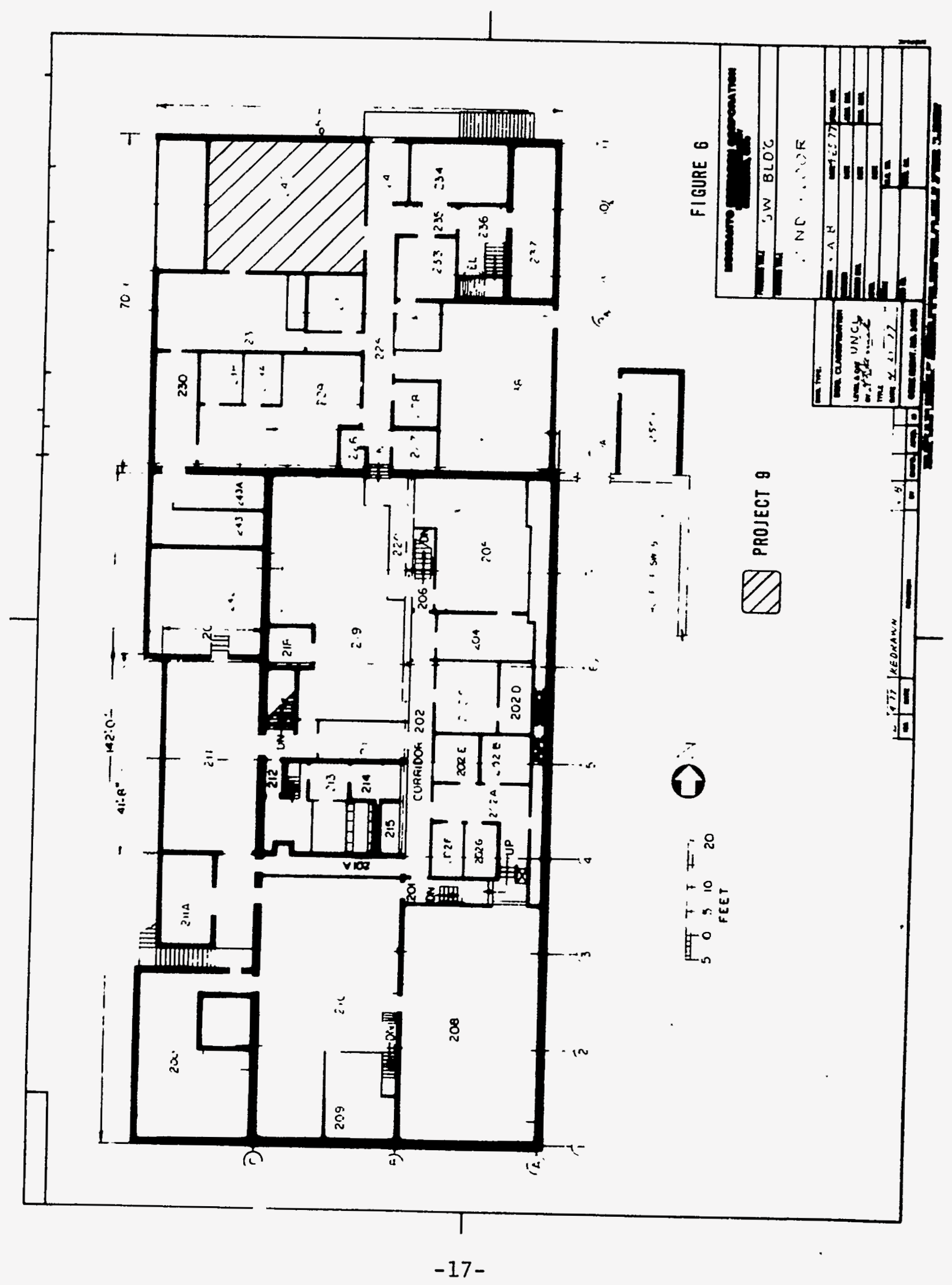




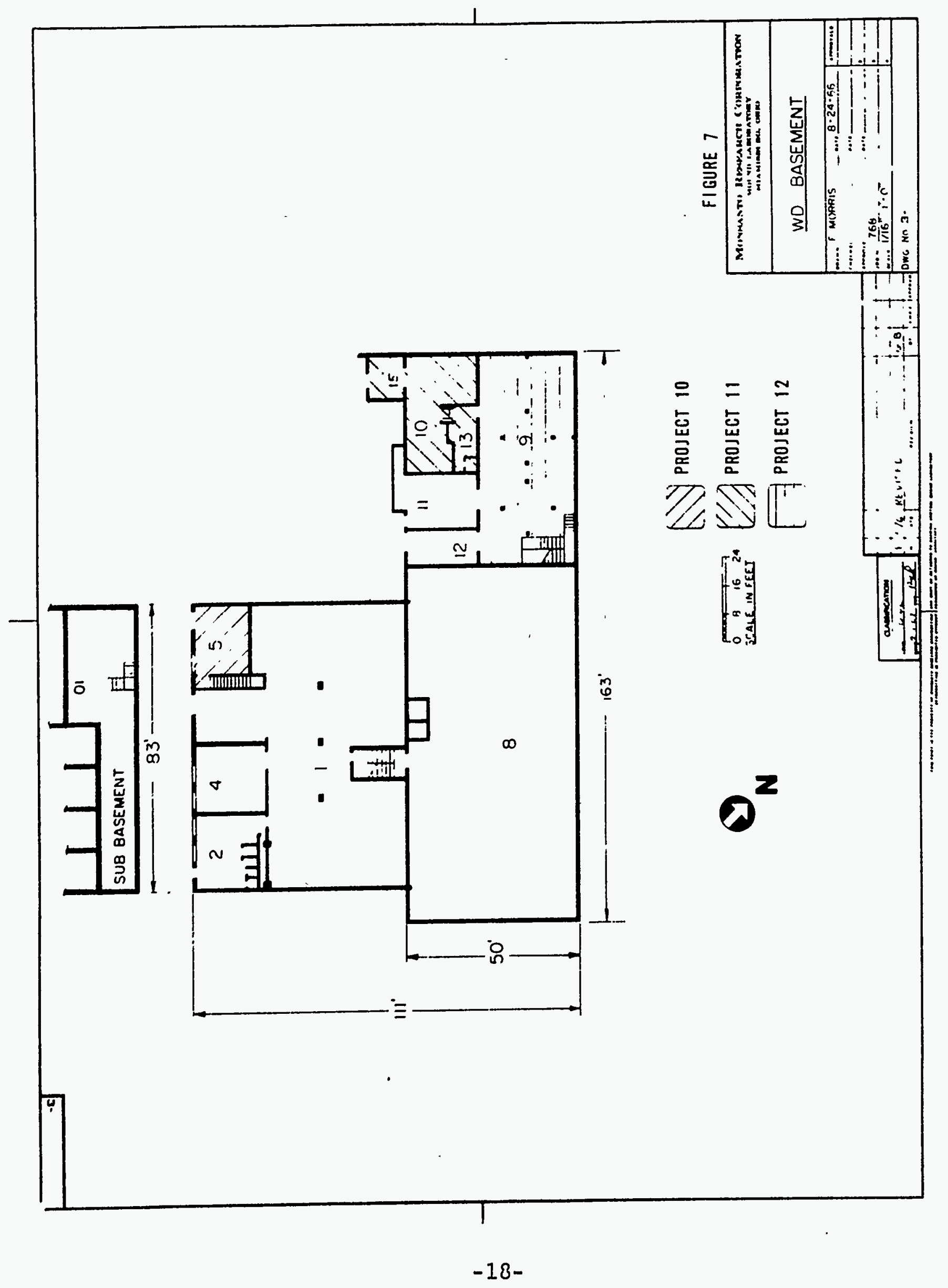


the volume of sludge by centrifugation is no longer required. The level of contamination is quite low, and the removal of the equipment will provide space for other low level activities in the field of waste management.

c) Funding

To be determined.

11. WD Building (WD 10, 13, 14, 15)

a) Description

Redrumming equipment, evaporators, tanks, and associated equipment in these rooms will be removed and the rooms restored (extensive decontamination) (see Figure 7).

b) Justification

Drumming of high level wastes from the PP Building was done in this area but no longer required as the high level waste is now being drummed in the new Waste Solidification Facility at the PP Building. Removal of this contaminated equipment will eliminate the hazard of potential low level release of radioactivity to the environment. The space is also valuable for some future programs in waste management.

c) Funding

To be determined.

12. WD Building (WD 9, 101)

a) Description

The two clariflocculators extending from Room 9 into Room 101 above will be removed with all associated pumps and piping (extensive decontamination). The rooms will be restored including filling the openings in the slab between floors (see Figures 7 and 8).

b) Justification

Two major changes have taken place in the past few 


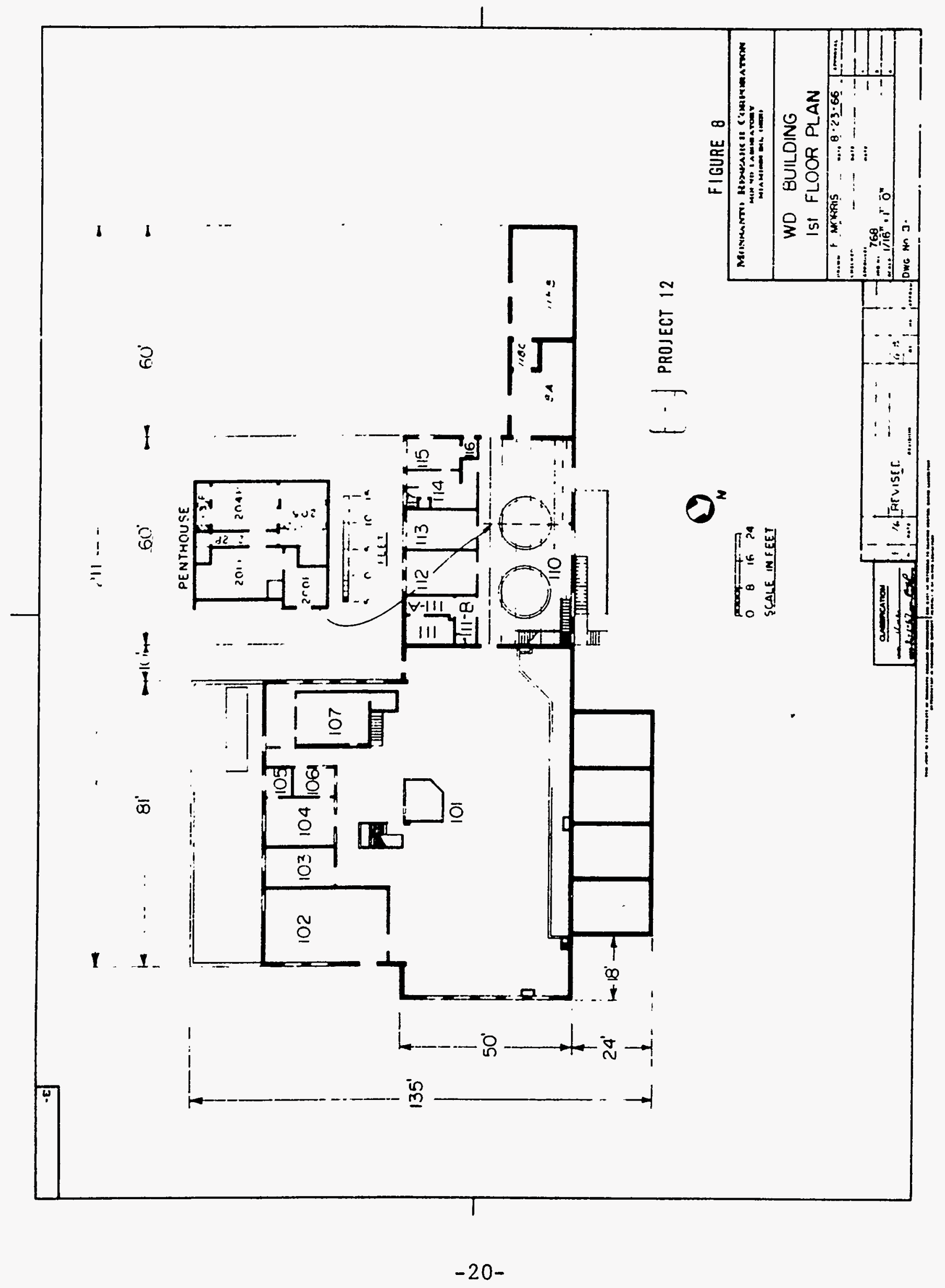


years rendering the two small clariflocculators excess. First, Polonium 210 is no longer processed at Mound Lab making it unnecessary to treat the Pu-238 in separate facilities. Secondly, a determined effort at good waste management has reduced the volume of waste generated to the point where the capacity of the two large clariflocculators in WD 101 is more than adequate.

c) Funding

To be determined.

13. Sanitary Sewage Septic Tank and Drying Beds (See Figure 9)

a) Description

The contaminated septic tank and the influent tank and associated equipment will be demolished (totally removed) and the area backfilled with clean earth. The adjoining drying bed with an area of about 1150 sq ft will be removed to a depth of about $3 \mathrm{ft}$ to an average contamination level of $11 \mathrm{pico} \mathrm{Ci} / \mathrm{g}$. As an alternate, the influent tank might be decontaminated by wet sand blasting and the concrete tank entombed.

\section{b) Justification}

The old sanitary sewage treatment plant has been replaced by a new treatment plant and has been abandoned. It is contaminated with $\mathrm{Pu}-238$, and removal of the system and drying beds will eliminate the potential low level hazard of contaminating the environment. It will also eliminate the need for maintenance and surveillance.

c) Funding

To be determined.

14. Site - Isolated Contaminated Areas (See Figure 9)

a) Description

A comprehensive program will be instituted for core sampling and analysis of previously identified sites 


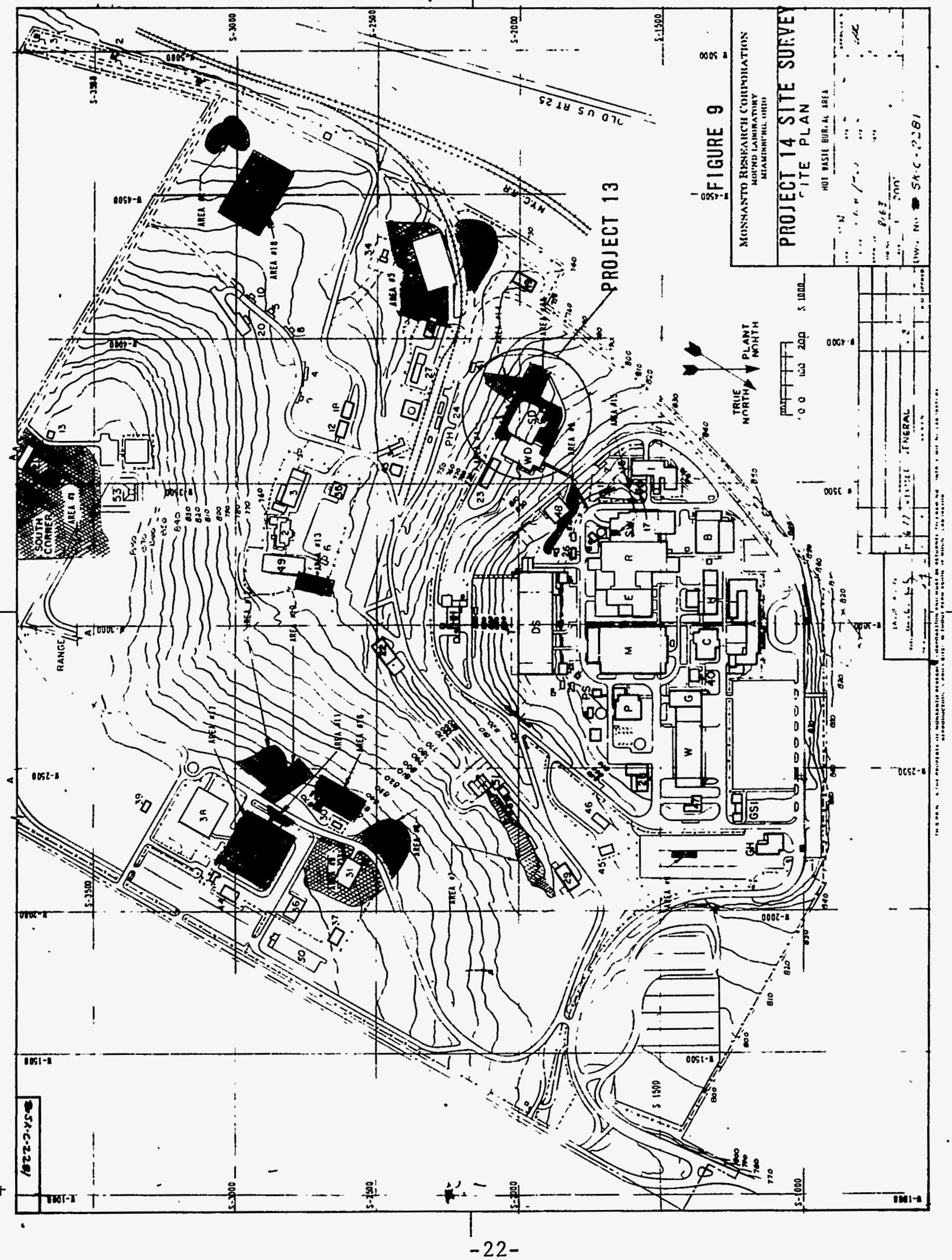


to accurately establish boundaries and depths of the contamination. Also, a comprehensive contamination survey of the entire site will be made to ascertain if there are contaminated areas not yet identified.

\section{b) Justification}

At present there is insufficient information to accurately determine the extent and quantity of previously identified contaminated soil that would have to be removed to meet the new guidelines of 11 pico $\mathrm{Ci} / \mathrm{g}$ of soil.

Also, since only suspected areas were sampled for contamination in the past, there is no assurance that all contaminated areas have been identified.

c) Funding

Funding for this survey is to be determined. The information derived from the surveys will provide the basis for estimating the cost to remove all contaminated soil from the site. It would then be necessary to amend the 10-year plan to incorporate these costs.

\section{Priorities and Costs}

The first four projects of the plan have been previously submitted in some form such as a Proposal (189) or Line Item. The costs and schedule indicated on the chart for these projects are taken from the respective submissions.

The balance of the projects are new with the costs in FY 1979 dollars, including the appropriate share of plant burden.

The schedule for these projects is based upon the phasing out of the functions and potential need for the facilities. The result, as noted in the chart, is a range of $\$ 51 / 4 \mathrm{mil}-$ lion to $71 / 2$ million per year through FY 1983. The period of FY 1984 through FY 1989 can then be reserved for the projects concerned with removal of contaminated soil which will be added later. This is feasible since the contamination is quite stable. 


\begin{abstract}
APPENDIX A
REFERENCE LETTER, PLANNING FOR DECONTAMINATION AND DECOMMISSIONING, H. E. ROSER TO J. A. CHACON DECEMBER 8, 1976
\end{abstract}




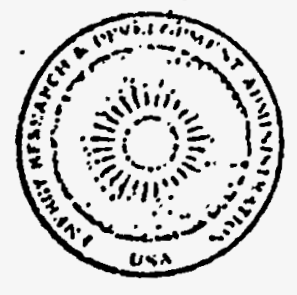

UNITEO STATES

ENERGY FESEARCH AHD DEVELOPA:ENT ADR:INISTRATION

ALAUOUERQUE OPERATIONS OFFICE

P.0. $0 \times 2900$

ALQUQUERQUE, NEH MEXICO 87115

$\because \quad$ DEC $8 \quad 1976$

R. R. Braziel, Area :'anager, LfAo

i. A. Chacon, Area Wanazer, DAO

W. M. Lamb, Area Nanager, RF 10

R. R. Maione, Area Hínager, S:O

PLARAIAG FOR DECONIALINATION ALD DECOMIISSIOALNG

In May, you farticipated in the development of an Alo 1 ist of radioactively contaruinated surplus ERDA facilities. However, since this list was restricted to only ertire buildir: $\tilde{s}$ or structures tiat woild be surplus to the identifiable needs of any EnDA prograris for the next five years, it by definition excluded sone additional potential decontanination or decomissioniag concerns. For example, the list -excluded land areas, fliloing portions, and buildings wich would become prograsuaticaily inactive but not necessarily surplus. Therefore, in order to rore completely develop the decontarination and. decomissioning picture, I have deciced to initiate tore comprenensive decontamination and lecormissioning planning. The pians are to encompass your clirrent site for a ten-year period and identify decontamination and decomissioning projects, project alternatives, . and pricrities.

The following two general types of projects are to be included in -the plans:

Type One Projects - Decontaminetion

: The following three general levels are recognized:

Readiness - initial clean-up; reactivation anticipated

-Stand-by - non-tixad contamination removed

: Extensive - internals removed

Iype Two Pzojects - Decomissioning

Ihree levels are also recognized; they are:

- Partial decontamination and entombment - Complete iecontamination and release for other use Demolition

Attachment 1 cortains additional guidelines for the Type one and Type Iwo Projects.

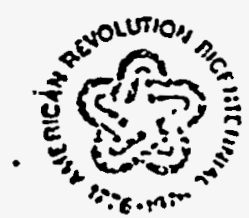


It should be roted that the atove projects are to ercluie equiprent which is removed from continuing operations. Firthermore, the cleanup of off-site areas is also to be excluced. The off-site areas may be added at a later date as a supplement to these initial plans.

The planning period for decontarination and decomissiouing projects Is to be ten years, FI 1980 thru FY 1989. Projects icientified for -decontamination and/or decommissionisg in this period are to be based on your interpretations of availajle programatic giidance regarding foreseeable utilization.

Your decontaunination and decomissioning plans should contain brief descriptions of and jusifications for the icientified projects. The - projects iderifified should be listed in a priority ranking with cost estimates in IF 1979 dollars and the type of flindisg indicated. Furthermore, since the Type one and Two projects of your prïority plan will be based on only one of the above levels of decontamination or decomissioning, if applicable, for each of these projects, alter-native levels of decontamination and decomissioning are. to be also Identified and estimated.

In conclusion, I realize that this request will require considerable effort on your part. However, I do believe that such projects cannot be routinely deferred and that they are a necessary portion of the rhort-range as well as long-range site managenent.

In order to allow Alo time for an evaluation of the projects regarding possible Inclusion in the FY 1980 bucget, please transmit your site plans by JuIy $15,1977$.

\section{.PRC:SKS $(620-76)$}

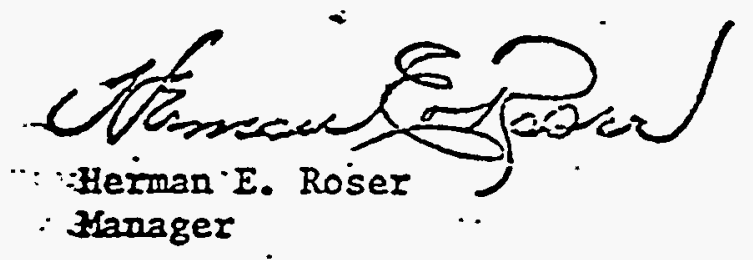

Enclosure:

$\therefore$ Guidance for l'ype Iwo and Three Projects

ince: Maj. Gen. J. K. Bratton, DSA, Director, DMA, HQ (w/encI) Martin B. Biles, Director, Div. of Safety, Standards, and Compliance, IIQ (w/encl) 
ATTACINEIT 1

Additional Guidelines for Tyve one and Two Projects

The following guideilnes provide a set of linits to be used for planning -purposes in the preparation of the Al 1G-year yaster Plan for Decontamination and Decomissionizg. However, we must emphasize that in all Instances, the As Low As Practicable (AIAP) radiatiọ exposure principal should be used.

1. ERDA 0524 concentration guides and exposure criteria provide acequate guldelines For personnel on-site and off-site for either an operating or an inactivated facility. Adiitionally, 0524 would also be applicable during the actual decontamination and derolition operations associated with decomissioning a facility.

2. For the release of radioactively contaminated equipnent, naterial, personal gear, etc., for uncontrolled use, the provisions of EXDA 109-45.50 should be followed. In sumary these limits are:

(a) 2000 disintegrations per minute (dpm) per $100 \mathrm{~cm} 2$ total for other than transuranium alpha emitters, 200 dpal per $100 \mathrm{~cm} 2$

$\therefore$ removable;

(b) $100 \mathrm{dpm}$ per $100 \mathrm{~cm} 2$ total for transuranium alpha emitters, * 20 dpm per $100 \mathrm{~cm} 2$ removable;

(c) 0.1 millirad per hour for itens of property known to have been in contact with strontiun 90, calciun 45, zirconiun 95, blsmuth 210 , or radium 226, measured at one centimeter through not more than a 7 milligram per square centimeter $(7 \mathrm{mg} / \mathrm{Cm} 2)$ absorbing material;

(d) 0.3 millirad per hour for beta and/or ganma emitters other than those listed in ( 3 ) above, measured at one centimeter

$\because \quad$ - through not more than 37 milligram per square centimeter (7mg/Cm2) absoribing naterial.

3. For the removal of soil for site decontanination, we suggest a value .of 11 plcocuries per gram of soil for transuranic radionuclides be used.

$\rightarrow$ The ratio of removable to total contamination and the $100 \mathrm{dpm} / 100 \mathrm{~cm} 2$ for trensuranic radionuclides was adopted from AlisI 1328 (draf:). 
4. The extent to which a faclifty/equipment/material to be retalned under ERDA control would have to be decontaninated to be placed Into an Inactive status would depend upon several factors: the Radioisotope(s) involved, the length of the inactive perfod, -projected future production effort and the time required to get back into productior, the type of facility, etc. Each facility or Item trust be evaluated on a case-by-case basis, and the approach chosen consistent with the provisions of ERDA 0524 and AISP. The following example which was prepared by Mound Labozatory shows - treps that right be undertaken to place a facility into various degrees of inactive status.

\section{Koind Laboratory Example}

A. Readiness: A conaition which will peralt full operation of a laboratory withia a short period of time (one calenciar quarter or less) after notification and with a wininum expenditure of funds. AIl operating equipment will remain .-In place and routine naintenance will be performed. No wipeable contanilation would exist in the laboratory areas, which is the case today. However, the average wipe level in the high rjisk areas, such as access corridors and building system equiprent areas, would be reduced to 2200 disintegrations per minute per $100 \mathrm{~cm} 2$ (dpm/100 $\left.\mathrm{cm}^{2}\right)$.

This Readiness condition applies to the physical plant only. Unless a comitment is also made to hold traired personnel, the staff will be decimated by layoff and transier. A recurn to full operation presupposes the inmediate availability of a

-nucleus of trained personel. Loss of staff rucleus would Iengthen operational readiness requirenent from one quarter to one full year.

-Operations to achieve this state are:

1. General cleaning of readily accessible areas and surfaces - within gloveboxes, access corridors and laboratory areas.

2. Flushing of process lines and vessels.

.3. Changing of all glovebox gloves and filters.

4. Disposing of scrap and waste materials resulting from clean-up activities. : .

5. Servicing of operating equipment. This will include frequent operation of in-line processing equipment to. assure its operability at all times.

-6. AlI major bullding süpport equipment will be kept operating. The major ouilding support equipment.

$$
-\frac{\dot{2}}{A-5}
$$


Includes the house vacuun, corrosive vapor, process chlll water and bullding ventilation systems. The emergency power systens will be Eaintained and checked to assure operability at all times.

7. Changing of all inert atmosphere boxes to an air supply to minimize procurement costs of laert gases.

8. Changing of appropriate building exhaust filters for areas to be placed in state-oi-readiness. ..

This condition may be maintained for a period of time not to exceed three (3) years. By the enc of this three-year period, thls readiness condition will be reevaluated for one of the following options:
a. The areas to be put back into operation.
b. The areas be partlally decontarinated (stand-by).
c. The areas be extensively decontaminated.
d. The areas be decotmissioned.

B. Partial Decontanination (stand-by): A condition which will permit full operation of a laboratory within a moderate period of tinte (witilia one year or less) after notification and with a reasonable expenciture of funds. The average wipe leveis In the high rish areas would be reduced to $220 \mathrm{dpa} / 100 . \mathrm{cm}$. Agaln, laboratory areas still exist because gloveboxes would - be in place. Therefore, the laboratory areas would be left with no wipeaile contamination, as they are today.

Operations required to achieve this stand-by condition Include -those operations stated in the above-readiness state, plusthe following:

1. More thorough cleaning of the gloveboxes, including all glovebox wells.

2. Removal of all degradable waterials and equipment from gloveboxes and support equipment. This includes - materials and equipsent that would not nortally be $\therefore$ expected to remain operational for the duration of $\because$ the stand-by condition. This degradable equipment

- would include electric motors, valves and glass

- components as examples.

3. Changing of all glovebox gaskets, both front and rear. The required building ventilation system and Health 
Physics monitoring equipwent will be maintained and serviced, in order to maintain radiological control of the facility. In addition, the energency power systems will de raintained and checked to assure. operability at all times.

The state of partial decontarination (stand-by) may be maintatined as long as the radiological safety of the -environtent is assured.

C.:- Extensive Decontamination: Extensive cecontanination includes the remcval of giovedoxes and contuminated services and ar. intensive decontamination of the Eacility. Since complete decontamination would require removal of the entire structure, the Eacility will be left "tainted;" i.e., - omall amounts of residial contamination would remein. This resldual contamination will be sealed and the facility .would remain uncer control and negative pressure to protect personnel and the environent.

The final exposed average contamination levels in the facility after this decontarination will be:

B. Wipe - $22 \mathrm{~d} / \mathrm{a} / 100 \mathrm{~cm}^{2}$

b. Direct $-3000 \mathrm{~d} / \mathrm{m} / 60 \mathrm{~cm}^{2}$

$\therefore$ c. . External radiation - less than $1 \mathrm{mr} / \mathrm{hr}$ at surface. 
DISTRIBUTION

External

J. A. Chacon, DAO (18)

R. K. Flitcraft, MRC

\section{Internal}

P. C. Adams

H. F. Anderson

A. G. Barnett

R. K. Blauvelt

R. P. Bowser

J. D. Braun

R. T. Braun

J. E. Caldwell

F. C. Capuder

W. T. Cave

W. P. Davis

D. A. Edling

T. C. Elswick

S. S. Freeman (6)

W. R. Harris

J. M. Garner

K. V. Gilbert

J. R. Geichman

J. F. Griffin

I. V. Jones

B. R. Kokenge

J. R. McClain

H. E. Meyer

M. L. Mullins

J. C. Requarth

D. E. Sellers

A. R. Stambaugh

F. A. Traino

R. E. Valleé

A. F. Vollmer

W. H. Westendorf

H. L. Williams

Publications

Library (6) 